\title{
Sustainability and Impact of Lean Six Sigma Practices: Learnings From Some KPO/BPO Organizations
}

\author{
Naresh Motiani, Abhay Kulkarni
}

\begin{abstract}
Sustainability is a major challenge while introducing changes to the organizational way of working. The paper studies sustainability of Lean Six Sigma (LSS) implementations in KPO/BPO (Knowledge Process Outsourcing/Business Process Outsourcing) industry. Five such case organizations that have implemented Lean Six Sigma practices in their Indian operations are studied. An exploratory case study method is adopted. The KPO/BPO case organizations are evaluated from four dimensions of people, process, technology and operational outcomes. Impact of Lean Six Sigma (LSS) practices on above four dimensions helps us to study and understand the underlying nature of relationships. Current study demonstrates some critical aspects that impact the sustainability of LSS implementations in case organizations. Business alignment, leadership commitment, tailoring LSS knowledge, and post implementation actions are some of the factors that play a critical role in the sustainability of LSS. This research has limitations of the case study method as it is limited to five case organization. Hence, the generalizations of findings and conclusions must be done cautiously. Further similar empirical studies in KPO/BPO's can possibly give more insights into independent and dependent factors and the correlations between them. This study has significant managerial and academic implications as the KPO/BPO industry is a growing sector of Indian economy. Published literature on LSS implementation in services sector has picked up over last decade, but there is very little literature in $\mathrm{KPO/BPO} \mathrm{sector.} \mathrm{This} \mathrm{paper} \mathrm{is}$ an attempt by researchers to contribute to this key area.
\end{abstract}

Keywords: Case Study, KPO/BPO, Lean Six Sigma, LSS, Outsourcing.

\section{INTRODUCTION}

Lean Six Sigma (LSS) is an integrated improvement framework based on Lean and Six Sigma principles. It has gained popularity among managers as it focusses on eliminating waste and reducing variation. This helps in improving cost, quality and timeliness. LSS is extensively used in manufacturing and published literature reveals it has been proved to be largely successful [1].

Evolution of LSS in manufacturing shows that it started with sectors such as automobiles and then got adapted to other sectors such as aircraft, electronics packaging, textiles, furniture, chemical, chemical, food and beverages and electrical and electronics [1]. Usage of LSS in services sector has lagged even though services dominate much of the GDP of almost all the major economies [2]. Primary reason cited for this is the intangible and heterogenous nature of services [3]. Thus, there is a need to adapt LSS in

\footnotetext{
Revised Manuscript Received on September 10, 2019.

Naresh Motiani, PhD Scholar, Symbiosis International (Deemed University), Pune, Maharashtra, India

(Email: nareshmotiani@yahoo.com)

Abhay Kulkarni, Research Guide and Director, IICMR, Nigdi, Pune, Maharashtra, India.

(Email: abhaykulkarni2@gmail.com)
}

various service sectors. One such service sector that has grown tremendously across the globe [4] since 1990's is KPO/BPO (Knowledge Process Outsourcing/Business Process Outsourcing) and is of interest for this study. The size of this sector is evident from the fact that in India alone this sector currently provides 1.9 million jobs along with revenue of USD 32 billion [5]. Revenues are further estimated to grow by over $65 \%$ to USD 54 billion by 2025 [6]. KPO/BPO is a part of overall Information Technology enabled Services (ITeS) outsourcing used by all Global 500 companies to primarily reduce costs and retain their competitive position [7]. This makes technology driven $\mathrm{KPO} / \mathrm{BPO}$ part of the global complex and dynamic supply chain [8]. Within India, BPO began in 1990's with American Express and GE gaining foothold with simple and manual data entry tasks. Key factors that have catapulted India to contribute over $40 \%$ in global KPO/BPO market [5] are large pool of graduates speaking English, favorable policies of government, favorable time zone difference with US, development of IT infrastructure, and adaptability of various $\mathrm{KPO} / \mathrm{BPO}$ service providers. Over a period, the BPO's took on more complex work and moved up the value chain of their clients and helped them with their critical and core business processes aka knowledge processes. This led to coining the term KPO (Knowledge Process Outsourcing) $[9,10]$. Table I shows the evolution and classification of $\mathrm{KPO} / \mathrm{BPO}$.

In this research study the term KPO/BPO refers to the knowledge processes which convert tacit data into explicit data or useful knowledge [11]. Such knowledge processes have some simple and manual process steps as well and hence term KPO/BPO is used [12].

Multiple challenges are faced by KPO/BPO operational manager that impacts operational outcomes. These challenges can be distilled into market driven, customer driven, managing interactions among people, process technology to achieve best operational performance. To manage these operational interactions various LSS operational models are used. Specific operational parameters need to be understood and their interactions among each other observed over a period to be able to predict some trends. Interactions and activities that have a cross functional nature, involve deeper understanding of domain knowledge, and the integrative play of multiple systems pose even bigger challenges. Scope for this research paper is to study these challenges faced by KPO/BPO operational managers during implementation and sustenance of LSS 
operational practices.

In absence of any empirical studies and integrative theories suited for KPO/BPO service operations, a case study method is used. This helps us to qualitatively undertake efforts to

Table I: KPO/BPO evolution since 1990's (inputs from various NASSCOM reports and industry experts)

\begin{tabular}{|c|c|c|c|c|c|c|c|}
\hline Timelime & 1900 & $199 \%$ & 2000 & 2005 & 2010 & 2015 & 2020 \\
\hline Competing Factor & \multicolumn{2}{|c|}{ Labour Afbitrage } & \multicolumn{2}{|c|}{ Process Improvement } & \multicolumn{3}{|c|}{ Process re-design and Automation } \\
\hline Cost Model & \multicolumn{2}{|c|}{ FIE baed } & \multicolumn{2}{|c|}{ FTE+ Transections } & $\begin{array}{c}\text { Trangartion } \\
\text { bassed }\end{array}$ & Outcome Based & Value Addition \\
\hline Processes & \multicolumn{3}{|c|}{ Non-coret transectional proceseseseg Oastomer sppout) } & \multicolumn{4}{|c|}{ Core Knowledge Basad (e.g. Big Data Analyics) } \\
\hline Techoolog & \multicolumn{2}{|c|}{ Mainframes } & Middlewar & \multicolumn{2}{|c|}{ Full ERP systems } & \multicolumn{2}{|c|}{ New Digital Technologies } \\
\hline Teminology & \multicolumn{7}{|c|}{ 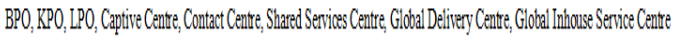 } \\
\hline
\end{tabular}

study the variables and the nature of interrelationships amongst them. Case study approach follows guidelines laid down by Yin [13] and is aimed to understand the "How" part. Keeping in mind scope the outlined above, we have formulated two research objectives i.e.

Objective 1: Study of sustainability of LSS practices implementations in KPO/BPO service organizations

Objective 2: Study the impact of LSS operations management models in the KPO/BPO industry

\section{A. Flow of Paper}

This research paper discusses the sustainability of LSS practices implementation and their impact on operational performance in KPO/BPO service organizations. Data is collected using primary and secondary sources to develop a qualitative understanding of research objectives mentioned earlier.

A brief introduction to research topic helps narrow down research objectives followed by literature review section (Section II) that attempts to uncover current understanding of services environment and challenges faced by operations managers in implementing and sustaining LSS. This also allows us to understand the impact on operational performance. Section III explains research methodology adopted for this research study and the rationale behind it. In Section IV data collection from the case organizations is described that have implemented LSS practices in their KPO/BPO operations. This is followed by Case discussion in Section V. Lastly Section VI summarizes conclusions and best practices from this research study along with various implications and limitations. Potential future scope is also briefly mentioned.

\section{LITERATURE REVIEW}

\section{A. Understanding KPO/BPO environment}

$\mathrm{KPO} / \mathrm{BPO}$ is part of ITeS (Information Technology enabled Services) as per NASSCOM industry categorization of IT outsourcing. Every KPO/BPO environment consists of three parties i.e. client (outsources its business process), service provider (performs business processes for the client) and customer (end user, client may sometimes be a customer). Multiple studies have contributed to the understanding of KPO/BPO environment [4, 14-18]. However, very few studies that help to cover the operations management topic which helps to understand how the
BPO's have moved up the value chain of knowledge processes [16]. Various authors have contributed to the growing knowledge such as Bharadwaj identifies competencies needed for successful relationship building with the clients [14]. Lacity et al., has done extensive review of published articles on BPO's to arrive at factors that affect BPO decision making (such as cost reduction, access to skills, continuous improvements, focus on core capabilities) and BPO outcomes (such as client communication, management capability, knowledge sharing, resource capabilities, cultural distance) [4]. Malik and Blumenfeld have discussed through a case study on how adoption of quality management systems positively impacts BPO organizational learning capability [15]. Sen and Shiel have used case study to discuss issues in moving up the value chain of outsourcing complex business processes [16]. Whitaker has empirically validated that organizations that have earlier outsourced their IT requirements or have international experience more likely to outsource their business processes [17]. Wüllenweber et al. has also empirically shown high correlation between process standardization and outsourcing of business processes [18]. This is quite natural as the business risks will be lower. While KPO work is highly profitable for service providers it also involves multiple risks seen both from client providers view. Mudambi and Tallman have discussed relational model to mitigate this risk as organizations move to outsourcing knowledge processes. They argue that outsourcing of knowledge processes involves a make-or-ally decision rather than make-or-buy for simple and manual business processes that can be standardized [19].

To summarize, due to the recent evolution of KPO/BPO sector and the dynamic nature the business environment there is propensity among businesses to outsource their knowledge processes. As KPO/BPO are keen to take knowledge work, operations managers need to find ways and means to mitigate client risks. This needs a careful analysis by academic researchers.

B. Challenges faced by operations managers and the issue of sustainability

Operations managers in KPO/BPO face many challenges involving managing of knowledge processes, such as developing and adapting appropriate service delivery models based on customer pull, defining appropriate metrics, measuring real time quality, putting appropriate controls, adopting technological changes, managing client relationship, keeping employees motivated, managing senior management, multiple interactions of processes and subprocess in service supply chain that they may not fully own, and adjusting to the intangible nature of services. Given current scope of research, focus will be understanding the sustainability challenge that can be directly addressed by LSS service operations model implementation in a knowledge process environment.

Sustainability is defined by Oxford Lexicon as "the ability to be maintained at certain rate or level" [20] 
Sustainability of LSS is an issue that concerns most organizations due to persistent change management effort needed to make LSS a success. Change must happen across the organization in beliefs and mindsets followed by multifaceted actions leading to operational and business outcomes that indicate if organization is imbibing the lean thinking. [24, 25]. Various challenges in sustaining the LSS thinking are ongoing top leadership commitment, project selection and prioritization, empowering front line decision making, customer centricity, problem solving mindset, linking LSS to organization bottom line, competency building at all levels, coaching and mentoring resources and aligning existing improvement efforts to LSS [21 - 23, 26].

\section{Evolution of LSS improvement methodology}

\section{1)}

\section{Lean Evolution}

Origins of lean are majorly attributed to evolution of lean at Toyota in 1950's, where core practices of lean i.e. JIT (Just in time), Defect Reduction, Jidoka (Autonomation with human touch), Waste elimination, Standard Work, flow concept, Kanban system, Continuous improvement, workload levelling emerged and were practiced [27]. Ohno has also credited Henry Ford for developing and applying some of first lean concepts in his moving assembly line system in 1913 [27]. Some of the other most prominent studies that exist documenting Lean thinking and practices are by Krafcik [28], Womack et al., [29] and Womack [30]. Womack et al., have described the concept of "Lean Factory" in their book "Machine that changed the world" [29]. Womack in his next book "Lean Thinking" outlined five principles of lean i.e. define value, map value stream, establish flow, create pull and achieve perfection [30]. Apart from manufacturing, lean has been extensively implemented in service sectors such as healthcare, insurance, IT outsourcing and banking [31, $32-36]$.

\section{2) Six Sigma Evolution}

Six Sigma has its origins in 1980's at Motorola and GE. It is based on a robust process improvement framework called as DMAIC (Define phase, Measure phase, Analyse phase, improve phase and Control phase) and aims to reduce variation in the process. Each phase has collection of tools and practices that help towards the goal of reducing process variation and defects. There are a good number of evidences in published literature of Six Sigma implementation in finance and banking, energy and utilities, healthcare, education, airline and customer services [21, 37]. Since six sigma implementation involves a significant resource commitment, there must be a careful consideration of various factors during its implementation [38]. Six Sigma implementation is usually driven through six sigma specialists such as Master Black Belt or Black Belt. American Society for Quality (ASQ) runs professional certifications program that ensures the specialists have a certain minimum competency.

\section{3) Lean Six Sigma Integrated Approach to Improvement}

Integrating Lean and Six Sigma brings natural advantages of both approaches in terms of cost, speed and defect reduction which are critical aspects of operational performance. Improvements in cost reduction has impact of reducing overall cost of operations, while improvements that improve speed of delivery and reduce defects have direct positive benefit for customers experience [39 - 41]. This makes an integrated approach of Lean Sigma Sigma highly appealing and popular among operations managers. It also merits that best projects be chosen keeping business strategy in mind and sometimes Lean or Six Sigma itself may suffice as improvement methodology, comparisons of two approaches should be avoided [26] and project need should mandate improvement methodology giving best returns on scarce resources invested in such improvement projects. There are three such types of projects loosely classified as Small Improvements (done by team directly and needing few days), Rapid Improvement Projects (done by managers and run up to a month) and Six Sigma projects (complex cross functional projects lasting up to six months and done under guidance of six sigma specialists). Once implemented, sustainability actions must be initiated to ensure processes do not fall back to the old ways. This is a major challenge since there is good amount of inertia during implementation (due to the leadership focus), however once the focus shifts on day to day execution changes do not sustain. Antony, Arcidiacono and Snee have suggested various best practices to mitigate the issue of sustainability $[22,23,26]$. Some of them are listed below:

- Comprehensive deployment covering implementation and a 30-60-90 day observation after handover to operations team

- Projects aligned to business objectives and impacting bottom line

- Competency building of teams to get general understanding of LSS methodology

- Commitment and active practice of LSS thinking by leadership

4) Various challenges in implementation of LSS operations models and operational performance in KPO/BPO

Since KPO/BPO's are essentially services they also have similar challenges such as lack of visibility, meaningful metrics, real time data, etc stated earlier in paper [42, 43]. As implementation of LSS is a significant investment by service provider, it would be beneficial if client also reciprocates and most ideal if it has also implemented LSS. Further, many business processes are critical to the client organization. Especially if these are complex strategic business processes, then there must be a strong relational and contractual governance must be in place [4]. Operational managers must strive to develop and practice these to continue outsourcing partnership as a strategic ally [19]. Operations managers must put enough controls in place that will establish a trail of how sensitive business information was handled during processing. Since knowledge processes are usually unstructured pieces of information and involve complex and subjective decision making, processes must be built and improved continuously 
to capture accurate customer requirements. A regular communication with the client and feedback can ensure that any gaps between actual service delivered and client expectations are addressed immediately. Equally important for knowledge processes is to define and agree operational performance in consultation with the client. These can be a mix of objective and subjective measures knowing that measuring knowledge process performance is a difficult area due to lack of any agreed framework and standards in published literature. Existing literature on knowledge process performance is summarized in Table II. Most common and minimum critical performance attributes cited by that seem common to all authors are quality, speed, flexibility, dependability and cost [44].

Table II: References to Knowledge Work Operational Performance adapted from Kropsu-Vehkapera \& Isoherranen [60]

\begin{tabular}{|c|c|c|}
\hline Author & Contest & Operational Performance \\
\hline Drucker, 1999 [45] & $\begin{array}{l}\text { Knowledge Worker Pefformance } \\
\text { Attributes }\end{array}$ & 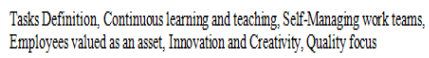 \\
\hline Ramirez, 2004, 2008 [46, 47] & Knowledge Worker productivity & Cost, Time, Quality, Imovation, Customer Satisfaction \\
\hline $\begin{array}{l}\text { Antitainen and Longqvist, } \\
2006[48]\end{array}$ & Knowledge workproductivity & $\begin{array}{l}\text { Imnovation, quality, effectiveness of innovation, time uxilization, customer } \\
\text { expectations }\end{array}$ \\
\hline Lacity et al., 2011 [4] & BPO outcomes & $\begin{array}{l}\text { Service Quality, Learring curve, Perfomanane improvements, Total outsourcing } \\
\text { success }\end{array}$ \\
\hline Davenport, 2015 [49] & Knowledge Work & Quality, Agility, Imovation, Customer Satisfaction \\
\hline Ruostela et al., 2015 [50] & Knowledge Worl Pefomance & $\begin{array}{l}\text { Productivity, Wooker Efficiency, Woiker Effectiveness, Results, Goals } \\
\text { Skills, Quality, Customer Satisfaction, Team Perfommance }\end{array}$ \\
\hline Palvalinet al, 2018 [51] & Knowledge Work & Efficiency, Productivity, Use of Knowedge \\
\hline
\end{tabular}

To summarize challenges KPO/BPO operations managers face are:

- $\quad$ Changing and increasing customer expectations

- $\quad$ Lack of standard metrics

- $\quad$ Employee engagement and motivation

- Adequate process controls to address issues of confidentiality and security

- $\quad$ Lack of skilled resources for knowledge processes

\section{Research gaps from Literature Review}

It is clear from literature review that little published literature exists on $\mathrm{KPO} / \mathrm{BPO}$ service operations management based on LSS framework. There is a strong need for such frameworks dealing not only with improvement projects but also day to day execution of knowledge process. The models should be cross functional and integrative, have strong customer orientation to cocreate, allowing iterative built up of knowledge process outputs. Published literature has qualitative case studies that can help in development of conceptual models and theories that can be empirically tested. These case studies are domain specific covering KPO/BPO work in healthcare, banking, insurance, utilities, pharma, oil and gas, shipping and transportation, legal services to name some. KPO/BPO Operational performance is also an area that needs to be studied [45]. As can be seen in Table II, this topic is an evolving area and there is no single solution. A mix of objective and subjective measures may help in better decision making by operations managers. It is evident from literature review that case study method is a popular method adopted for theory building. We have summarized gaps into following research questions
Research Question 1: How are the sustainability issues addressed by KPO/BPO during and after LSS operations framework implementation?

Research Question 2: How are LSS operations frameworks implemented by KPO/BPO organizations for managing service operations?

Research Question 3: What are the best practices for measuring the impact of LSS framework implementation?

\section{RESEARCH METHODOLOGY}

\section{A. Rational for research method selection}

Researchers have chosen to adopt an exploratory case study research method. The decision is driven by lack of existing published frameworks and theories on LSS service operations model for $\mathrm{KPO} / \mathrm{BPO}$ service environment. Exploratory case study method gives qualitative insights of underlying events and interactions between various process level and sub-process level factors [52 - 54]. A multi-case study gives an advantage by allowing us to see similarities and dissimilarities of observed variables in multiple scenarios. This helps to build theories and possibly explore on the nature of variables and interactions [55].

Current research is part of ongoing field research by researchers starting June-2018 by reaching out to five different KPO/BPO organizations that have implemented LSS as part of service operations management in multiple ways. Selection of case organizations is based on convenience to get widest representation across KPO/BPO sector covering 3rd party and captive setups, Indian and foreign owned and spanning across multiple industry sectors/domains. In all above organizations both knowledge work and manual/transactional work exists but focus of study is on knowledge work.

\section{B. Data Collection}

To address the known limitations of a case study method, a case study protocol was designed as per guidelines by Yin [13] covering project overview, field protocol, case study questions, and case study report. During a brief first connect with the case organizations implementation leaders were made aware of aims and objectives of the study and their willingness to participate in research. Once they consented, a semi-structured interview schedule was shared to allow interviewers to familiarize with the questions. This allowed some flexibility to add more relevant info. A standard protocol for all case organizations was to collect primary data through semi-structured interview which were voice recorded for accurate transcription. Transcribed notes were sent to interviewers for review and confirmation and final consent. In addition to semi-structured interview where ever permitted by organization policies a brief floor visit was done to see implementation of LSS practices. Along with primary data, secondary data was also accessed. This was both internal and external and served to mostly reinforce primary data and in few cases, fill the gaps in primary data. For example, if top management commitment was 
mentioned as one of factors for implementation, then implementation progress reports mentioning regular reviews with the functional delivery head filled gaps in terms of mere commitment or active involvement of senior leaders

- Table III summarizes primary and secondary data collection for all case organizations which are named as $\mathrm{C} 1$ to $\mathrm{C} 5$. Denzin has also recommended such triangulation of data from multiple sources in person, time and space to overcome deficiencies in any one data source [56].

Table III: Summary of Primary and Secondary Data collection for Case Organizations C1, C2, C3, C4 and C5

\begin{tabular}{|c|c|c|c|c|c|}
\hline & $C l$ & $C_{2}$ & $C 3$ & $C 4$ & $C 5$ \\
\hline Primary Data:Mode & $\begin{array}{l}\text { Face to face Intervien } \\
\text { at site }\end{array}$ & Interview and at site & Interview Telephonic & $\begin{array}{l}\text { Face to face Interniew } \\
\text { at site }\end{array}$ & $\begin{array}{l}\text { Face to face Interviex } \\
\text { at site }\end{array}$ \\
\hline Primary Data:Source & $\begin{array}{c}\text { Site Master Bladk } \\
\text { Belt (MBB) }\end{array}$ & $\begin{array}{l}\text { Site GM Lead Biach } \\
\text { Belt }\end{array}$ & $\begin{array}{l}\text { Lean Transformation } \\
\text { Leader }\end{array}$ & AVP Transformation & $\begin{array}{c}\text { Head Transformation } \\
\text { Program }\end{array}$ \\
\hline Protocol Brieféd & Yes & Y'es & Yes & Yes & Yes \\
\hline Voice Recording & Yes & Yes & Yes & Yes & Yes \\
\hline Duration of Intervew & $2.5 \mathrm{hrs}$ & 2 hrs & $1.5 \mathrm{mirs}$ & 1.5 his & $1.5 \mathrm{lirs}$ \\
\hline On floor observations & Yes & Yes & No & No & No \\
\hline Secondary Data & Yes & Yes & Yes & Yes & Yes \\
\hline Implementationplans & Yes & Yes & Yes & Yes & Yes \\
\hline Training Manuals & Yes & Yes & Yes & Yes & Yes \\
\hline Orget up & Yes & Yes & Yes & Yes & Yes \\
\hline Floor practices & Yes & Yes & Yes & Yes & Yes \\
\hline Performane Dashboard & Yes & Yes & Yes & Yes & Yes \\
\hline Project Portfolio & Yes & Yes & Yes & Yes & Yes \\
\hline Company Anual tepots & Yes & Yes & Yes & Yes & Yes \\
\hline Maturity Assessment & Yes & Yes & Yes & Yes & Yes \\
\hline
\end{tabular}

\section{CASE STUDY}

\section{A. $\quad$ Case Context and Organization Brief}

Names of the case organizations have been kept hidden on request. Using a common research protocol table IV elaborates details of the five case organizations such as their core business, nature of KPO/BPO, regional base, clients/domains supported, head count details, years since lean sigma practices, any LSS specialist roles and reporting details, LSS competency and sustenance actions.

\section{B. Data Collection in case organizations on LSS} operations model implementations

Primary case data for all organizations was collected through semi-structured interviews. Based on literature review of LSS implementations in a service environment an interview schedule covered following areas of LSS operations management framework implementation.

- Specific implementation approach covering various LSS practices

- Various stakeholders in implementation and their role

- Walk through of an implementation cycle focussing on people, process and technology

- Adoption/integration of technology in LSS operations model

- Tangible and intangible outcomes expected from LSS implementation

- Operations performance attributes and performance metrics examples adopted

- At least two examples of implementations with baseline and improved operational performances

$$
\text { - Challenges encountered during }
$$
implementation and sustenance

- $\quad$ Some best practices evolved during implementation
Table V below briefly summarizes data collected on LSS operations model implementations

Table IV: Details of case organization context and organizational brief for five cases i.e. C1, C2, C3, C4, C5 (names not revealed on request)

\begin{tabular}{|c|c|c|c|c|c|}
\hline & $\mathrm{Cl}$ & $\mathrm{C}_{2}$ & C3 & C4 & $C 5$ \\
\hline Organization core busininss & $\begin{array}{l}\text { Global IT player } \\
\text { providing IT support } \\
\text { services }\end{array}$ & $\begin{array}{l}\text { Global MNC } \\
\text { providing } \\
\text { Tramsportation } \\
\text { services }\end{array}$ & $\begin{array}{c}\text { Gilobal MNC } \\
\text { providing outsourcng } \\
\text { services of business } \\
\text { process }\end{array}$ & $\begin{array}{c}\text { Global MNC } \\
\text { investment bank and } \\
\text { financial services } \\
\text { provider }\end{array}$ & $\begin{array}{c}\text { Indian owned } \\
\text { providing outsourcing } \\
\text { setrices of business } \\
\text { processes }\end{array}$ \\
\hline Nature of KPOBPO & 3d Party setup & Captive setup & 3id Party setup & Captive setup & $3^{\text {nid part setup }}$ \\
\hline Regional'Country Base & North America & European & North America & European & Indian \\
\hline $\begin{array}{l}\text { Clents across the } \\
\text { domain industry suppoted } \\
\text { by service provider }\end{array}$ & $\begin{array}{l}\text { IT support shared } \\
\text { services }\end{array}$ & Logistics and Shipping & $\begin{array}{l}\text { Banking, Insurance, } \\
\text { Utilities, Healthcare, } \\
\text { Life Sciences, } \\
\text { Automotive }\end{array}$ & $\begin{array}{l}\text { IT support services } \\
\text { and financial products } \\
\text { support }\end{array}$ & $\begin{array}{l}\text { Banking, Insurance, } \\
\text { Utilities, Healthare, } \\
\text { Automotive, Travel }\end{array}$ \\
\hline Global Head Count & $3,00,000+$ & $80,000+$ & $80,000+$ & $40,000+$ & $1,50,000+$ \\
\hline KPOBPO Head Count & $80,000+$ & $10,000+$ & $80,000+$ & $6.000+$ & $15,000+$ \\
\hline $\begin{array}{l}\text { Number of Years in Lean } \\
\text { Six Sigma }\end{array}$ & 10 & 10 & 20 & 10 & 15 \\
\hline $\begin{array}{l}\text { Improvement Specialists } \\
\text { Role }\end{array}$ & Yes & Yes & Yes & Yes & Yes \\
\hline $\begin{array}{l}\text { Full Time Prit time } \\
\text { eppoting }\end{array}$ & Full time & Full time & Full time & $\begin{array}{l}\text { Full time Inovotion } \\
\text { ttams, Change teams }\end{array}$ & Full time \\
\hline LSS Trainings & Yes & Yes & Yes & Yes & Yes \\
\hline $\begin{array}{l}\text { Naturity Assessment } \\
\text { Reports }\end{array}$ & Yes & Yes & Yes & Yes & Yes \\
\hline
\end{tabular}

Table V: Case Data Collection on LSS service operations model

\begin{tabular}{|c|c|c|c|c|c|}
\hline & $\mathrm{Cl}$ & $C_{2}$ & $\mathrm{Cl}$ & $C 4$ & $C$ \\
\hline $\begin{array}{l}\text { Name of operations } \\
\text { mannagement framewook in } \\
\text { case orgarization }\end{array}$ & $\begin{array}{l}\text { DOEF (Delivery } \\
\text { Operational Excelleace } \\
\text { Framevork). }\end{array}$ & $\begin{array}{l}\text { DPEM(Delivery } \\
\text { performance } \\
\text { excellence model) }\end{array}$ & $\begin{array}{c}\text { LDF } \\
\text { (Lean Diagnosic } \\
\text { Framework) }\end{array}$ & Process Excellence & $\begin{array}{c}\text { OPEX } \\
\text { Operational } \\
\text { Excellence }\end{array}$ \\
\hline Foundations & $\begin{array}{l}\text { Toyota Production } \\
\text { System and DMAIC }\end{array}$ & $\begin{array}{l}\text { PDSA, Deming's } \\
\text { theory, Systemic } \\
\text { thinking }\end{array}$ & $\begin{array}{l}\text { Lean Design, } \\
\text { Lean Thinking, } \\
\text { DMAIC }\end{array}$ & $\begin{array}{l}\text { Lean Thinking and } \\
\text { DMAIC }\end{array}$ & Lean Six Sigma \\
\hline Implemeritation Approach & 5 phases & 2 phasess & 4 phases & 3 phases & 5-phase DMAIC \\
\hline Period of implementation & 20 weeks & 4 weeks & 15 weeks & Up to 26 weeks & $12 \cdot 24$ weeks \\
\hline $\begin{array}{l}\text { Key componenents of the } \\
\text { framework }\end{array}$ & $\begin{array}{l}\text { Delivery Syytem, } \\
\text { Management System, } \\
\text { mindset andcapbibilifies }\end{array}$ & $\begin{array}{l}\text { Improvement Project } \\
\text { (Mobilise, Analyse, } \\
\text { Pilot, Rollout, } \\
\text { Stabilize, Kaizen) and } \\
\text { Lean Process } \\
\text { Management }\end{array}$ & $\begin{array}{l}\text { Lean Deigg, } \\
\text { Prototype Validation, } \\
\text { Technology } \\
\text { Integration, Service } \\
\text { Delivery }\end{array}$ & $\begin{array}{c}\text { Engineer } \\
\text { performance, } \\
\text { Techinology analysis, } \\
\text { Improve Service } \\
\text { product }\end{array}$ & Lean and DMAIC \\
\hline Maturity Assessment & Yes & Yes & Yes & Yes & Yes \\
\hline Sale & 4 levels & 5 levels & Customized & Custonized & Customized \\
\hline Competency Building & $\begin{array}{l}\text { Mandatotory - } 1 \text { day for } \\
\text { teams, } 1 \text { week for } \\
\text { leaders }\end{array}$ & $\begin{array}{l}\text { Need Based, } 1-10 \\
\text { days based on job role }\end{array}$ & $\begin{array}{l}\text { Black Belt, Green } \\
\text { Belt and Yellow Belt }\end{array}$ & $\begin{array}{l}\text { Yes - need based } \\
\text { online platforms }\end{array}$ & $\begin{array}{l}\text { Yes }-1 \text { days is } \\
\text { mandatory }\end{array}$ \\
\hline
\end{tabular}

\section{C. $\quad$ Data on Phase Wise Deployment details}

Phase wise deployment of LSS operations model were captured for each case organization. This contained detailed LSS practices that were used or implemented during various phases. Information was captured on the number of phases, LSS practices used, flexibility in implementation, change management and any best practices adopted during deployment. Attention was also given on how the LSS framework support day to day execution and challenges faced by operations managers. Table VI shows phase wise detailed information for all five cases i.e. C1, C2, C3, C4 and $\mathrm{C} 5$.

\section{CASE DISCUSSION RESULTS}

Considering the research questions and objectives formed earlier, we have observed how variables related to LSS implementation and sustenance operate in the KPO/BPO

Published By: Blue Eyes Intelligence Engineering 
services environment. Based on variables uncovered during primary and secondary data in a KPO/BPO environment we now compare these variables across the five case organizations. Both qualitative and quantitative data are used as per guidelines by Yin [13] and Eisenhardt [57]. Studying the behavior of these variables brings deeper understanding of how these operate and leads us to building new theories or fine-tuning existing theories. Cross case analysis is

Table VI: Data collection on phase wise implementation details for five case organizations

\begin{tabular}{|c|c|c|}
\hline Case Organization & ProjectPhases & Key Tools Used \\
\hline \multirow{5}{*}{$\begin{array}{l}\text { Cl } \\
\text { Delivery Operations } \\
\text { Excellence } \\
\text { Framework }\end{array}$} & P1-Identify Phase & Process mapping, Performancemanagement, Resourcemapping \\
\hline & P2-Baselime & Value stream mapping-currentstste \\
\hline & P3-Future State & Value stream mapping. Future State, Lean Levers \\
\hline & P4-Deployment & $\begin{array}{l}\text { WorkLoad Lerellimg, Dispatching } \\
\text { Standard Work, Daily Hudde, MeasurementPlan }\end{array}$ \\
\hline & P5-30.60-90 follow up & Continuous improvement, standard assesment \\
\hline \multirow{2}{*}{$\begin{array}{l}\text { C2 } \\
\text { Delivery } \\
\text { Performance } \\
\text { Excellence Model }\end{array}$} & $\begin{array}{l}\text { P1-Buid ImproveProcess } \\
\text { (optional) }\end{array}$ & Mobilise, Analyse, Pilot, Rollout, Stabbilize, Kaizen \\
\hline & P2-RumProcess & $\begin{array}{l}\text { Daily Malagement, Visual Managgment System, Gemba, Contimuous Improvement, Kaizen, Standard } \\
\text { Work }\end{array}$ \\
\hline \multirow{4}{*}{$\begin{array}{l}\text { C3 } \\
\text { Lean Diagnostic } \\
\text { Framework }\end{array}$} & P1-Lean Desiggn & $\begin{array}{l}\text { Customer joumey mapping, Value stream mapping, Brimstoming, Lateral thinking, Design team, } \\
\text { Benchmatking, Standard Work, Validations, Aggle Practice, Changeblocks, hackathon days }\end{array}$ \\
\hline & P2-Lean Validation & $\begin{array}{l}\text { Priortization, Risk asssmment, Cost benefit analysis, Client telationship, Prototyping team, Upstream } \\
\text { waste analysis }\end{array}$ \\
\hline & P3-Prototype Validation & Process standardization, Automation, RPA, machime, leaning, OCR, Project teams \\
\hline & P4-SericiceDelivery & $\begin{array}{l}\text { Contimoors improvement, Daly Management, Lean Assesment, Client Performance revierss, } \\
\text { Standard Work }\end{array}$ \\
\hline \multirow{3}{*}{$\begin{array}{l}\text { CA } \\
\text { Process Excellence }\end{array}$} & P1-Engineer perfomance & $\begin{array}{l}\text { Design thinking, value strem mapping, braimstoming, agle practics, fmancial risk analysi, } \\
\text { perfomancemeasurement, mprovementroadmap }\end{array}$ \\
\hline & P2-Technology analysis & RPA, Coganitivémelligence, user testing \\
\hline & $\begin{array}{l}\text { P3-Improve Sertice } \\
\text { product }\end{array}$ & Elminate waste, standard work, performance dashboards, risk management, teggulatory controls \\
\hline \multirow[t]{2}{*}{$\begin{array}{l}\text { C5 } \\
\text { Operational } \\
\text { Excellence }\end{array}$} & P1-ImproveProcess & 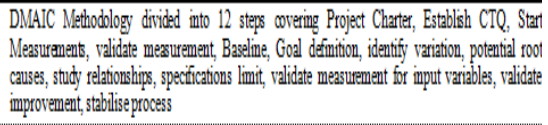 \\
\hline & P2-RumProcess & $\begin{array}{l}\text { Improverment roadmap, Contimuous improverament, waste reduction, peformance dashboards, standard } \\
\text { worl, bestpractices sharing, objectives aligument }\end{array}$ \\
\hline
\end{tabular}

built on research protocol and prevents any bias due to people interviewed or even that of the researchers [57]. Primary and Secondary data presented in previous section and tables IV, V, and VI are used to discuss the case study using various interrelated factors.

\section{A. Organization factors} management. We looked at organization cost driver i.e. weather it is a cost centre (a captive service centre set up by a parent organization e.g. Mastercard Global Business Services Centre) or a revenue centre (a 3rd party service provider serving multiple clients across one or multiple domains e.g. Accenture). Data from the case organizations shows two of them i.e. $\mathrm{C} 2$ and $\mathrm{C} 4$ are captives (cost centres for parent organization). $\mathrm{C} 1$ and $\mathrm{C} 5$ are 3rd party (acting as revenue business unit and having multiple clients) IT and business support services provider respectively and part of their larger parent organization. C3 is a 3rd party fully integrated service provider of outsourced business processes. For each of above case organizations, their strategic alignment is decided by their parent organization in terms on areas such as growth plans, technology focus, investments and annual goals. Except C3 which is a fully
Organization factors have a direct impact on operations

integrated KPO/BPO player, for all other case organizations their alignment to their parent organizations may introduce strategy variations unless they are fully independent to set their own strategy and make such choices. Another important critical success factor that is common to all implementations is the top management commitment [39]. Taking a deeper look into five cases it was observed that in all the cases top management commitment exists and has mandated use of an improvement framework (each organization uses different name shown earlier). The commitment manifests in multiple ways indicating the depth of involvement. One of the interviewees summarized this by saying that "While commitment to LSS is always there, in practice some leaders choose to delegate things which they must not do".

\section{B. LSS framework Implementation factors}

From various case studies variations are observed in the implementation of LSS framework. These can be seen in multiple dimensions such as timelines, scope flexibility of the framework itself and functional coverage, creation of client or function specific roadmaps, contribution to the annual goals, and support of improvement specialists such as black belts. Maximum time flexibility is seen for $\mathrm{C} 4$ while least is seen for $\mathrm{C} 1$. Scope flexibility is higher for captives i.e. C2 and C4 compared to 3rd party. Captives have the option of picking and choosing certain elements of the framework which are more suitable for given business requirement. 3rd parties usually insist on implementing entire framework as they consider it as foundational to further continuous improvement. In terms of the implementation roadmap C1, C3 and C5 consult, agree and get a signoff from their clients before starting implementation. $\mathrm{C} 2$ and $\mathrm{C} 4$ align their implementation roadmaps to their parent organization corporate goals and strategic plans.

\section{Human Factors}

Human factor is at the heart of LSS framework [27, 57, 59]. We discuss this in the context of LSS implementation to cover competency building, change management, and group platforms to allow team members to contribute towards the goal of continuous improvement. It is observed that $\mathrm{C} 1, \mathrm{C} 3$ and C5 have comprehensive training programs for all employees in building LSS competency. They have training programs ranging from 1-day to 4 days and is mandatory to be completed. For $\mathrm{C} 2$ and $\mathrm{C} 4$ the training is based on business pull or special drives conducted by improvement specialists from time to time. It is common to offer LSS certifications to the team members (such as white belt, yellow belt) to get greater a buy-in. In all five case there is a recent trend to move training programs on an online platform. In order to tap the creative potential of the teams all five case organizations have an idea contribution platform and a detailed implementation process, which is hosted on their intranet site. This helps to drive bottom up improvements and sharing of best practices while improving the engagement levels. 


\section{LSS Framework Details}

Across all the five cases we have observed that the core LSS practices remain common however they vary in integration and implementation. There is also a variation in terms of orientation of practices either towards lean or six sigma. It is known that lean focusses on waste elimination (cost and speed), six sigma focusses on defect reduction (quality) this may be the possible reason for such orientation. Implementation structure also shows variation across five cases and it varies from five phases for $\mathrm{C} 1$ to 1 phase (with additional optional phase) for case organizations $\mathrm{C} 2$ and C4. Similarly, project methodology is DMAIC for C1, C3 and C5. C2 uses its own project methodology based on PDSA (Plan-Do-Study-Act) cycle. Lean practices seem easier to adapt for day to day execution and six sigma tools are more suitable for complex improvement projects. Detailed practices are shown in Table VI. To manage multiple projects all five case organizations have a project portfolio management function at client, functional, or account level. This includes project selection and prioritization. It is observed that projects are aligned to the business or client goals.

\section{E. Sustainability Actions}

Sustainability is cited as a common challenge [21, 22] and multiple actions are put in place by all five case organizations. Most common are periodic maturity assessments of on floor practices, review of progress on LSS implementation plans by senior management and benefits tracking for implemented improvement projects. It was seen that the periodic assessments were customized for each case organization. $\mathrm{C} 1$ followed a 4-scale maturity assessment model, C2 has 5-scale maturity assessment model, C3 and $\mathrm{C} 4$ each have a compliance report with customized items to be assessed. C5 has a composite index that measures both practices implementation and the performance outcomes. These maturity assessments were the means of coaching floor teams to improve implementation and effectiveness of LSS practices. Reviews by senior management such as functional or delivery head is a consistent practice and is done either with a Master Black Belt or as part of projects portfolio review. There were also some unique ways of senior management review in $\mathrm{C} 2$ where senior leaders visit floor to directly see implementation and effectiveness of practices. This practice is referred to as "Doing Gemba" which has origins from Toyota [21]. Kaizen program discussed earlier for five case organizations was also observed as an important practice for LSS framework sustenance.

\section{F. Impact of LSS implementation}

All five KPO/BPO case organizations intend to achieve improved operational performance outcomes through LSS framework which are shown in Table VII below. Three
Table VII: Impact of LSS framework implementation on operational performance

\begin{tabular}{|c|c|c|}
\hline & Indicator & Specific Improvements \\
\hline \multirow{3}{*}{$\mathrm{Cl}$} & Cost & $\begin{array}{l}5 \% \text { productivity improvement, USD } 1.2 \text { million annual } \\
\text { benefits }\end{array}$ \\
\hline & Speed & Ticket resolution time reduced by $20 \%$ \\
\hline & Quality & First time incident resolution improved by $15 \%$ \\
\hline \multirow{3}{*}{$\mathrm{C} 2$} & Cost & $10 \%$ productivity improvement from December baseline \\
\hline & Speed & Booking request processing time reduced by $30 \%$ \\
\hline & Quality & Reduced accounts receivable invoice errors by $25 \%$ \\
\hline \multirow{3}{*}{$\mathrm{C} 3$} & Cost & $20 \%$ costreduction in accounts payable processing team \\
\hline & Speed & Improved dispute resolution time by over $80 \%$ \\
\hline & Quality & $\begin{array}{l}\text { Improved accounts payable invoice auto match by } 125 \% \text { in } \\
\text { high } 90 \text { 's }\end{array}$ \\
\hline \multirow{3}{*}{$\mathrm{C} 4$} & Cost & $25 \%$ efficiency improvement of equity research process \\
\hline & Speed & Reduced equity underwriting processing time by $40 \%$ \\
\hline & Quality & Reduced VAT refunds processing defects by $30 \%$ \\
\hline \multirow{3}{*}{$\mathrm{C} 5$} & Cost & $5 \%$ productivity gain leading to USD 4 million savings \\
\hline & Speed & $\begin{array}{l}\text { Improved claims processing time by } 60 \% \text { bringing it within } \\
\text { a day }\end{array}$ \\
\hline & Quality & Reduced warranty claims by $20 \%$ for FMCG major \\
\hline
\end{tabular}

The case organizations commit significant resources to making this part of the organizational way of working Three common indicators were chosen and data from primary and secondary sources was analyzed. While these are tangible outcome measures there were also tangible lead measures that were being tracked. Example of lead measure is completion of process trainings and certifications which impacts quality. Similarly, cross functional competency improves flexibility.

Apart from tangible measures, there are intangible measures [35] that are commonly seen in a service environment. These are also observed in the five case organizations. Example is a continuous improvement mindset. A common attribute for this across the five case organizations is use of kaizen program with various operational definitions and different set of measurements. One case organization applied the criteria as one-week timeline and a self-driven improvement, while another had month long timeline and a green belt actively involved during implementation. There are also different names used internally in each case organization.

Further a one-page view of cross-case analysis discussed so far is shown in Table VIII for various factors such as Organization factors, Implementation factors, Human Factors, Framework Details and Sustainability Actions 
Table VIII: Summary of cross-case analysis of 5 case organization for various factors of LSS operations management framework implementation and sustenance

\begin{tabular}{|c|c|c|c|c|c|}
\hline Criteria & Cl & C! & $C^{3}$ & Ct & $C$ \\
\hline \multicolumn{6}{|l|}{ Orgunization factors } \\
\hline CostDrivers & $\begin{array}{l}\text { RerentueBusiness } \\
\text { Unit( } 3^{\mathrm{A}} \text { Patty) }\end{array}$ & $\begin{array}{l}\text { CostBusismess Unit } \\
\text { (Captrie) }\end{array}$ & 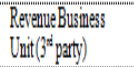 & $\begin{array}{l}\text { CostBusiness Cuit } \\
\text { (Captre) }\end{array}$ & 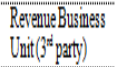 \\
\hline $\begin{array}{l}\text { Strategic Alligument } \\
\text { towadds }\end{array}$ & Client & Parent & Client and Technology & Parent & Client \\
\hline $\begin{array}{l}\text { Top Vlavagement } \\
\text { Commibnent }\end{array}$ & Yes, mandatory & $\begin{array}{l}\text { Yes, bred on bisimess } \\
\text { pull }\end{array}$ & Yes, mandatory & $\begin{array}{l}\text { Yes, bred on bisimess } \\
\text { pull }\end{array}$ & Yes, mandatory \\
\hline \multicolumn{6}{|l|}{ Implementation factors } \\
\hline $\begin{array}{l}\text { Tonelinefor } \\
\text { inplementation }\end{array}$ & 201weeks & 4 weelks mimim & 15 wreeks & Upto 26 wreeds & 12 weels minmum \\
\hline $\begin{array}{l}\text { Scope of selecting LSS } \\
\text { elements / Time flexibility }\end{array}$ & Yes $/$ No $_{0}$ & Yes Y Yes & $\begin{array}{l}\text { Yes Yess } \\
\text { Clientspectic } \\
\text { 10admap }\end{array}$ & Yes Yes & $\begin{array}{l}\text { No Yes } \\
\text { Clientspecific } \\
\text { coadmap }\end{array}$ \\
\hline $\begin{array}{l}\text { ImproverementSPecialist } \\
\text { (MBB, BB) guidance }\end{array}$ & Yes & Yes & Yes & Yes & Yes \\
\hline \multicolumn{6}{|l|}{ Human Factors } \\
\hline LSS training mandatory & Yes & No, based on pull & Yes & No, based on pull & Yes \\
\hline LSS Training aburation & 4 days & Iday & 3days & Iday & Iday \\
\hline \multicolumn{6}{|l|}{ FrameworkDetals } \\
\hline Practices & AllLSS practices & AllLSS practices & $\begin{array}{l}\text { AllLSSpractices and } \\
\text { Lean Desigyn }\end{array}$ & AllLSS practices & AllLSS practices \\
\hline Projects Wethodology & Yes, ie.DMAIC & Yes, Le.Customized & Yes,DMAIC & YesDMAIC & Yes,DMAIC \\
\hline Kaizen Program & Yes & Yes & Yes & Yes-plaform & Yes \\
\hline \multicolumn{6}{|l|}{ Sustain ablity Actions } \\
\hline Amual Benefitis Iracking & $\begin{array}{l}\text { Yes, and shared with } \\
\text { dient }\end{array}$ & $\begin{array}{l}\text { Yes, partofffunctional } \\
\text { projectportiolio }\end{array}$ & $\begin{array}{l}\text { Yes,erievededrith } \\
\text { Client }\end{array}$ & Yes & Yes,AccountLerel \\
\hline Sustenderce & Yes,4 LevelMaturity & Yes, Slevel Maturity & $\begin{array}{l}\text { Yes, No Maturity } \\
\text { Scale-quartely } \\
\text { compliance }\end{array}$ & Yes-customized & $\begin{array}{l}\text { Yes, inder coverimg } \\
\text { practices and } \\
\text { outcomes }\end{array}$ \\
\hline $\begin{array}{l}\text { LSSImplementation } \\
\text { Dashboowd }\end{array}$ & $\begin{array}{l}\text { Yes (reviewed with } \\
\text { deliverylead) }\end{array}$ & $\begin{array}{l}\text { Yes (revierved with } \\
\text { functional lead) }\end{array}$ & $\begin{array}{l}\text { Yes (reviewed with } \\
\text { deliverylead and } \\
\text { dient) }\end{array}$ & $\begin{array}{l}\text { Yes (erviewed with } \\
\text { functional lead) }\end{array}$ & $\begin{array}{l}\text { Yes (erverwed with } \\
\text { deliverylead and } \\
\text { dient) }\end{array}$ \\
\hline
\end{tabular}

\section{OVERALL CONCLUSION}

Using a qualitative case study method, we have studied sustainability and impact of LSS practices implementations in selected KPO/BPO organizations. Qualitative research has revealed that each implementation was customized and unique though there were some similarities and core practices of LSS were followed. Researchers have observed key variables and some best practices for implementation and sustenance. The variations observed are primarily driven by organizational factors such as cost driver and strategic alignment. Top management commitment is a must in all cases to ensure smooth implementation. Active involvement of senior leaders beyond commitment further accelerates LSS framework implementation. Timelines for framework implementation vary widely due to extent of depth and width of implementation.

Similarly, giving flexibility to operations managers to decide their timelines ensures smoother implementation through competency building, concepts application and internalizing the practices. Support from improvement specialists greatly improves the implementation speed and effectiveness. It is important for leadership to tie LSS framework implementation with business goals and objectives. Thus, goals alignment across all levels of the organization is important. A comprehensive communication explaining LSS framework as a key enabler to achieve organizational and personal goals. Buy-in from operations managers is a key step in this direction as they are direct touchpoints for teams on the floor. Teams need to undergo LSS trainings to equip them with relevant knowledge of

LSS framework and various tools and practices. Post training some handholding and follow up by dedicated improvement specialists or line managers ensures there is an ongoing support for practicing newly learnt framework. It was also mentioned multiple times by experts that a small improvement followed by a certification answers the question teams have i.e. "What's in it for me?".

Case study clearly reveals that the usage of LSS practices forms the core of LSS framework. LSS pool of practices that were observed were lean design, value stream mapping, problem solving, standard work, kaizens, 5S workplace organization, knowledge management, customer journey mapping, lateral thinking, agile practices, project prioritization, risk assessment, cost benefit analysis, client relationship, prototype testing, upstream waste analysis, standardization, automation, continuous improvements, daily management and latest digital technologies such as RPA, machine learning and big data analytics.

One of focus areas that gets missed out by these frameworks is managing day to day processes. This study also reveals some best practices on daily management that help the teams doing knowledge work.

- A daily management routine made part of team's standard work helps the teams to organize better in terms of managing daily workload and actual resources at hand

- Daily morning huddles (stand up meetings) help teams to develop planning mindset, share latest process information and discuss ways of collaborating on specific client requirements

Simple on floor visual boards done by the teams help in work load levelling, address daily backlogs before they become unmanageable

Teams are self-directed and manage their own tasks [45]

Regular floor Go See visits by operations managers and senior leaders with the teams help reinforce LSS practices and address bottlenecks faced by the teams

Various sustainability actions at multiple levels and multiple frequencies help in ensuring that LSS framework is being used, thus helping drive operational performance. Practices that engage and incentivise the teams and make them part of decision making have higher buy-in. This not only leads to consistent performance, but also improves the process continuously in turn helping it sustain. Sustainability practices observed in case study are kaizen program, project benefits tracking, project reviews, quarterly LSS maturity assessments, and LSS implementation dashboard.

Study also reveals lack of standard metrics specific to knowledge processes. A mix of objective and subjective metrics are used for measuring performance [35]. Most common metrics such as cost, time, quality, flexibility and customer services are implemented, and part of performance dashboard used for reviews with management and client.

Overall, we have observed LSS practices are adapted for $\mathrm{KPO} / \mathrm{BPO}$ environment though there is no standard model for KPO/BPO. These practices seem to have mostly positive 
impact on operational performance. With some structured actions the issue of sustainability is also addressed.

This study is unique as there is little published literature dealing with LSS in KPO/BPO and researchers have attempted to contribute in this important and growing field.

\section{A. Research Limitations and Implications}

Limitations of this study stem from fact that a qualitative case study method is adopted. Though this method reveals rich information on "How" the variables interact in the case context, it has a limitation in terms of generalization. Using five case studies and a cross-case analysis may address this issue to some extent but it not a replacement for empirically validated models. This study is unique to best of our knowledge and contributes to growing field of KPO/BPO sector. Managers will find case study useful as there are plenty of best practices discussed which will help them improve their cost, quality and speed of delivery. However, these should be adopted with caution as mentioned earlier due to the limitations of study method used. The academic community will find this study helpful for theory building in this field.

\section{B. Scope for future research}

Future research through more such case studies will strengthen theory building and help us to fully understand the variables at play. There is a need to build conceptual and theoretical frameworks and then empirically validate them. This would greatly contribute to our understanding of how outsourced knowledge processes can be managed. This will tremendously improve success rate of LSS implementations.

\section{REFERENCES}

1. Albliwi, Saja, et al. "Critical failure factors of Lean Six Sigma: a systematic literature review." International Journal of Quality \& Reliability Management 31.9 (2014): 1012-1030.

2. World Bank (2018), World Development Indicators: Structure of output, World Bank, http://wdi.worldbank.org/table/4.2

3. Lovelock, Christopher, and Evert Gummesson. "Whither services marketing? In search of a new paradigm and fresh perspectives." Journal of service research 7.1 (2004): 20-41.

4. Lacity, Mary C., et al. "Business process outsourcing studies: a critical review and research directions." Journal of information technology 26.4 (2011): 221-258.

5. NASSCOM (2018). The IT-BPM Sector in India 2018 : Amplify Digital, http://www.nasscom.in/knowledgecenter/publications/the-it-bpm-sector- india-2018amplify-digital

6. NASSCOM IBEF IT-ITeS-Report-May-2018 (2018) https://www.ibef.org/download/IT-ITeS-Report-June2018.pdf

7. Barney, Jay. "Firm resources and sustained competitive advantage." Journal of management 17.1 (1991): 99-120.

8. Ramachandran, K., and Sudhir Voleti. "Business process outsourcing (BPO): emerging scenario and strategic options for IT-enabled services." Vikalpa 29.1 (2004): 49-62.

9. Gill, Edward. "Knowledge process outsourcing and the legal sector: the Evalueserve approach." Legal Information Management 12.1 (2012): 16-24.
10. Agarwal, Ranjana, and Syeedun Nisa. "Knowledge process outsourcing: India's emergence as a global leader." Asian Social Science 5.1 (2009): 82-92.

11. Nonaka, Ikujiro, Ryoko Toyama, and Noboru Konno. "SECI, Ba and leadership: a unified model of dynamic knowledge creation." Long range planning 33.1 (2000): 5-34.

12. Snieška, Vytautas, and Aura Drakšaitè. "The role of knowledge process outsourcing in creating national competitiveness in global economy." Engineering Economics53.3 (2007).

13. Yin, R. K. "Case study research: Design and methods. sl: Thousand Oaks." (1994).

14. Bharadwaj, Sangeeta S., Kul Bhushan C. Saxena, and Murthy D. Halemane. "Building a successful relationship in business process outsourcing: an exploratory study." European journal of information systems 19.2 (2010): 168-180.

15. Malik, Ashish, and Stephen Blumenfeld. "Six Sigma, quality management systems and the development of organisational learning capability: Evidence from four business process outsourcing organisations in India." International Journal of Quality \& Reliability Management 29.1 (2012): 71-91.

16. Sen, Falguni, and Michael Shiel. "From business process outsourcing (BPO) to knowledge process outsourcing (KPO): Some issues." Human Systems Management 25.2 (2006): 145-155.

17. Whitaker, Jonathan, Sunil Mithas, and Mayuram S. Krishnan. "Organizational learning and capabilities for onshore and offshore business process outsourcing." Journal of Management Information Systems 27.3 (2010): 11-42.

18. Wüllenweber, Kim, et al. "The impact of process standardization on business process outsourcing success." Information Systems Frontiers 10.2 (2008): 211-224.

19. Mudambi, Susan M., and Stephen Tallman. "Make, buy or ally? Theoretical perspectives on knowledge process outsourcing through alliances." Journal of management studies 47.8 (2010): 1434-1456.

20. Sustainability (2019), Oxford Lexico Dictionary, https://www.lexico.com/en/definition/sustainability

21. Antony, Jiju, et al. "Six sigma in service organisations: Benefits, challenges and difficulties, common myths, empirical observations and success factors." International journal of quality \& reliability management 24.3 (2007): 294-311.

22. Antony, Jiju. "Six Sigma vs Lean: Some perspectives from leading academics and practitioners." International Journal of Productivity and Performance Management 60.2 (2011): 185-190.

23. Arcidiacono, Gabriele, Nico Costantino, and Kai Yang. "The amse lean six sigma governance model." International Journal of Lean Six Sigma 7.3 (2016): 233266.

24. Coleman, James S. "Social theory, social research, and a theory of action." American journal of Sociology 91.6 (1986): 1309-1335.

25. Coleman, James S., and James Samuel Coleman. Foundations of social theory. Harvard university press, 1994. 
26. Snee, Ronald D. "Lean Six Sigma-getting better all the time." International Journal of Lean Six Sigma 1.1 (2010): 9-29.

27. Ohno, Taiichi. Toyota production system: beyond largescale production. crc Press, 1988.

28. Krafcik, John F. "Triumph of the lean production system." MIT Sloan Management Review 30.1 (1988): 41.

29. Womack, James P., et al. Machine that changed the world. Simon and Schuster, 1990.

30. Womack, James P., and Daniel T. Jones. "Lean thinking - banish waste and create wealth in your corporation." Journal of the Operational Research Society 48.11 (1997): 1148-1148.

31. Schonberger, R. J. "World class manufacturing: the lessons of simplicity applied. 1986."

32. Apte, Uday M., and Chon-Huat Goh. "Applying lean manufacturing principles to information intensive services." International journal of services technology and management5.5-6 (2004): 488-506.

33. Bowen, David E., and William E. Youngdahl. "'Lean" service: in defense of a production-line approach." International journal of service industry management 9.3 (1998): 207-225.

34. Gupta, Shradha, Monica Sharma, and Vijaya Sunder M. "Lean services: a systematic review." International Journal of Productivity and Performance Management 65.8 (2016): 1025-1056.

35. Sunder M, Vijaya, L. S. Ganesh, and Rahul R. Marathe. "A morphological analysis of research literature on Lean Six Sigma for services." International Journal of Operations \& Production Management 38.1 (2018): 149182.

36. Staats, Bradley R., David James Brunner, and David M. Upton. "Lean principles, learning, and knowledge work: Evidence from a software services provider." Journal of operations management 29.5 (2011): 376-390.

37. Antony, Jiju, and Ricardo Banuelas. "Key ingredients for the effective implementation of Six Sigma program." Measuring business excellence 6.4 (2002): 20-27.

38. Nakhai, Behnam, and Joao S. Neves. "The challenges of six sigma in improving service quality." International Journal of Quality \& Reliability Management 26.7 (2009): 663-684.

39. Setijono, Djoko, Alessandro Laureani, and Jiju Antony. "Critical success factors for the effective implementation of Lean Sigma." International Journal of Lean Six Sigma (2012).

40. Salah, Souraj, Abdur Rahim, and Juan A. Carretero. "The integration of Six Sigma and lean management." International Journal of Lean Six Sigma 1.3 (2010): 249274.

41. Sangwa, Narpat Ram, and Kuldip Singh Sangwan. "Development of an integrated performance measurement framework for lean organizations." Journal of Manufacturing Technology Management 29.1 (2018): 41-84.

42. Armistead, Colin. "Service operations strategy: framework for matching the service operations task and the service delivery system." International Journal of Service Industry Management 1.2 (1990): 6-16.

43. Arnheiter, Edward D., and John Maleyeff. "The integration of lean management and Six Sigma." The TQM magazine 17.1 (2005): 5-18.

44. Slack, Nigel, Michael Lewis, and Hilary Bates. "The two worlds of operations management research and practice: can they meet, should they meet?." International Journal of Operations \& Production Management 24.4 (2004): 372-387.

45. Drucker, Peter F. "Knowledge-worker productivity: The biggest challenge." California management review 41.2 (1999): 79-94.

46. Ramírez, Yuri W., and David A. Nembhard. "Measuring knowledge worker productivity: A taxonomy." Journal of intellectual capital 5.4 (2004): 602-628.

47. Ramirez, Yuri W., and Harry J. Steudel. "Measuring knowledge work: the knowledge work quantification framework." Journal of Intellectual Capital 9.4 (2008): 564-584.

48. Antikainen, Riikka, and Antti Lönnqvist. "Knowledge work productivity assessment." Institute of Industrial Management. Tampere University of Technology. PO Box 541 (2006): 79-102.

49. Davenport, Thomas H. "Process management for knowledge work." Handbook on Business Process Management 1. Springer, Berlin, Heidelberg, 2015. 17 35.

50. Ruostela, J., Lönnqvist, A., Palvalin, M., Vuolle, M., Patjas, M., \& Raij, A. L. (2015). 'New ways of working'as a tool for improving the performance of a knowledge-intensive company. Knowledge management research \& practice, 13(4), 382-390.

51. Palvalin, Miikka, Vilma Vuori, and Nina Helander. "The relation between knowledge transfer and productivity in knowledge work." Knowledge Management Research \& Practice 16.1 (2018): 118-125.

52. Eisenhardt, Kathleen M., and Melissa E. Graebner. "Theory building from cases: Opportunities and challenges." Academy of management journal 50.1 (2007): 25-32.

53. Meredith, Jack. "Building operations management theory through case and field research." Journal of operations management 16.4 (1998): 441-454.

54. Yin, R. K. " Case study research: Design and methods (Vol. 5) sl: Thousand Oaks." (2003).

55. Silverman, David. Doing qualitative research: A practical handbook. SAGE publications limited, 2013.

56. Denzin, Norman K. The research act: A theoretical introduction to sociological methods. Routledge, 2017.

57. Eisenhardt, Kathleen M. "Building theories from case study research." Academy of management review 14.4 (1989): 532-550.

58. George, Michael. Lean Six Sigma for Service, Chapter 2Getting Faster to Get Better: Why You Need Both Lean and Six Sigma. McGraw Hill Professional, 2003.

59. Shah, Rachna, and Peter T. Ward. "Lean manufacturing: context, practice bundles, and performance." Journal of operations management 21.2 (2003): 129-149.

60. Kropsu-Vehkapera, Hanna, and Ville Isoherranen. "Lean approach in knowledge work." Journal of Industrial Engineering and Management (JIEM) 11.3 (2018): 429444.

\section{AUTHORS PROFILE}

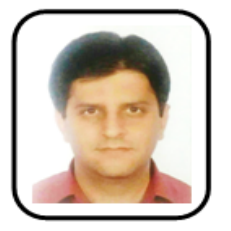

Naresh Motiani has over 18 years of industry experience spanning various companies in the manufacturing and service sector. $\mathrm{He}$ is also currently pursuing $\mathrm{PhD}$ from Symbiosis International (Deemed University). His research interest lies in lean operations and supply chain 
management, digital technologies and knowledge process outsourcing. He is a Master Black Belt and a PMP ${ }^{\circledR}$ certified project manager.

Dr. Abhay Kulkarni has over 34 years of corporate and academic experience and currently Director of IICMR Institute in Pune, India. He is a registered $\mathrm{PhD}$ guide and member of Board of studies at Pune University. He has published and presented research papers in various academic journals and National and International conferences and published a post graduate level book on Services Business Management (ISBN:978-93-5273-489.4). He is a certified Master Black Belt and has research interests are in area of process excellence, teaching and corporate coaching. 